\title{
Nine-year monitoring of cambial seasonality and cell production in Norway spruce
}

Kyriaki Giagli ${ }^{(1)}$, Jožica Gričar ${ }^{(2)}$,
Hanuš Vavrčík $^{(1)}$, Vladimír Gryc ${ }^{(1)}$

\section{Introduction}

Norway spruce (Picea abies [L.] Karst.) is one of the most widespread coniferous species in Europe (Skrøppa 2003) and has a considerable commercial importance. Changing environmental conditions might lead to a potential decrease in growth and yield of this species (Bošela et al. 2014). Over the last years, several studies have been conducted on the xylogenesis of Norway spruce with the aim of investigating the plasticity of the species in terms of cell production (Desplanque et al. 1998, Mäkinen et al. 2003, Battipaglia et al. 2009, Schuster \& Oberhuber 2013, Boden et al. 2014), mostly in relation with the extreme environmental conditions predicted by future climate change scenarios (IPCC 2013).

Previous studies on Norway spruce have demonstrated that the annual wood formation period lasts from three to seven months, varying from April until October depending on site conditions (Rossi et al. 2008, Cuny et al. 2012). It has been reported that the temperature is a crucial factor

We analyzed the relationship between weather conditions and year-to-year (1981-1989) variation in the seasonal dynamics of cambial cell production (CCP) in Norway spruce in a monoculture forest area in the Czech Republic. We found that the timing of CCP greatly varied among the studied years. The onset of CCP occurred at the beginning of May and was strongly correlated with the April mean temperature. CCP ceased by the end of August. The timing of the cessation of CCP was more variable among trees and among years than its onset. The amount of precipitation positively influenced the duration of CCP and the average rate of cell production positively correlated to the minimum temperature in January-April, as well as the maximum temperature during the growing period. Our results show that the timing and the rate of CCP of xylem cells are influenced by temperature and precipitation. However, weather-xylem growth relations of spruce from temperate forests under climatic conditions are complex, since trees are known to respond less strongly to climatic average variation than influences of extreme conditions.

Keywords: Picea abies, Temperature, Precipitation, Wood Formation, Xylem Increment, Light Microscopy

for cambial activity and cell development at the beginning of the growing season, while other factors prevail later (Gričar et al. 2007). Gričar et al. (2014) specified that mean temperature in April was strongly correlated with the onset of Cambial Cell Production (CCP). Similarly, Körner (2003) pointed out that temperature primarily triggers phenological phases in this species. Furthermore, according to many studies, both daily tree growth and the duration of CCP in conifers are influenced by the minimum temperature, rather than the maximum (Richardson \& Dinwoodie 1960, Deslauriers \& Morin 2005, Rossi et al. 2008, Li et al. 2012). As regards with high elevation sites, Norway spruce responds positively to the mean temperature in summer months, while the response is negative at lower elevations (Levanič et al. 2009). Nevertheless, an increase in mean summer temperature is usually associated with a decrease in precipitation, which is considered to be quite a limiting factor in case of lower altitudes (Bošela et al. 2014). In
(1) Mendel University in Brno, Faculty of Forestry and Wood Technology, Department of Wood Science, Zemedelska 3, 61300 Brno (Czech Republic); (2) Slovenian Forestry Institute, Vecna pot 2, SI-1000 Ljubljana (Slovenia)

@ Kyriaki Giagli (giagli@node.mendelu.cz)

Received: Jul 15, 2015 - Accepted: Oct 05, 2015

Citation: Giagli K, Gričar J, Vavrčík H, Gryc V (2016). Nine-year monitoring of cambial seasonality and cell production in Norway spruce. iForest 9: 375-382. - doi: 10.3832/ifor1771-008 [online 2016-01-16]

Communicated by: Paolo Cherubini addition to temperature, water availability was also found to affect the seasonal dynamics of wood formation and radial cell dimensions of tracheids in Norway spruce (Horáček et al. 1999, Jyske et al. 2010). Gričar et al. (2014) reported that the phenology of CCP is highly variable and plastic among years, since Norway spruce has the ability to adjust CCP in order to function optimally in local environmental conditions. However, weather-xylem growth relations of Norway spruce growing under average climatic conditions in temperate forests are not easily detected, since trees respond less strongly to climatic variation than to extreme conditions (Mäkinen et al. 2003).

In the Czech Republic, Norway spruce covers approximately $45 \%$ of the land (Ministry Report 2014) and is the most important commercial softwood timber. In this study, 9-year observations of the seasonal dynamics of CCP in Norway spruce growing in the Czech Republic in the 1980 s (from 1981 to 1989 ), provides a long-term dataset

\section{List of abbreviations}

- CCP: Cambial Cell Production

- SPI: Standardized Precipitation Index

- SPI $I_{\text {annual: }}$ Annual Standardized Precipitation Index

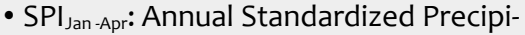
tation Index from January to April

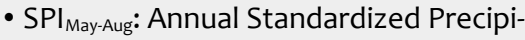
tation Index from May to August

- WY: Water Years

- GDD: Growing Degree Days

- DOY: Day of the Year 


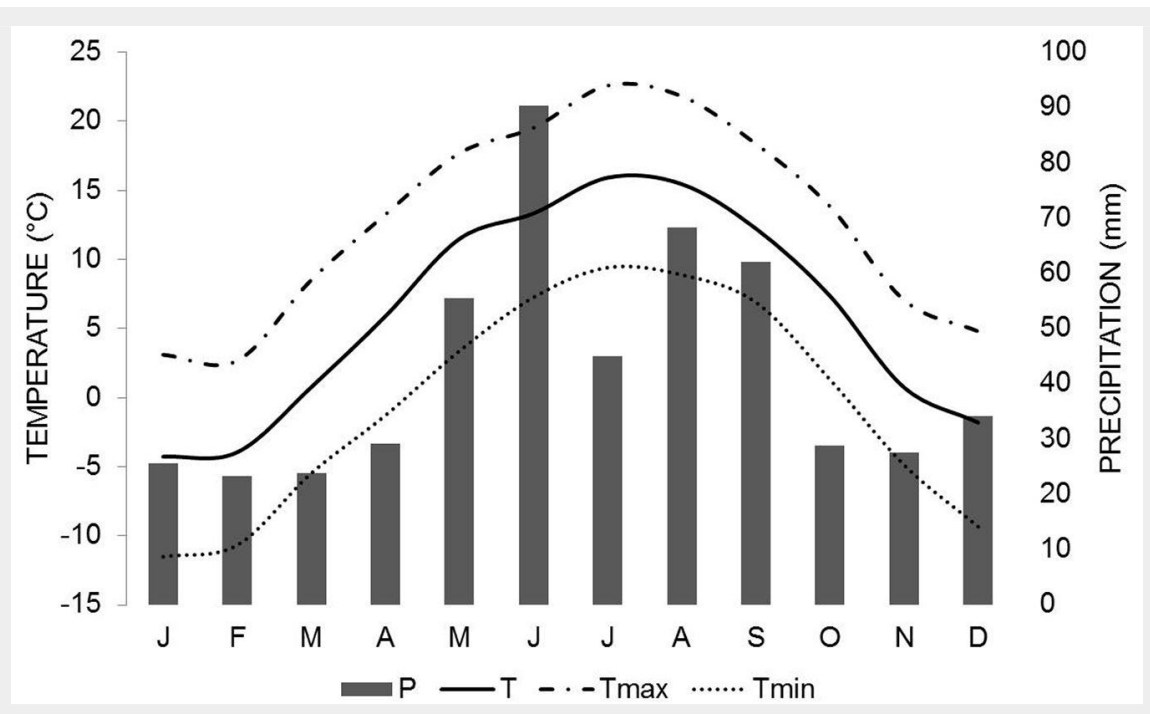

Fig. 1 - Climate diagram of the study area for the period 1981-1989. Lines represent the mean monthly temperature, monthly maximum and monthly minimum temperature, while bars represent the total monthly precipitation (Protivanov weather station, (zech Republic).

of its radial growth patterns thirty years ago. Datasets of long-term monitoring of xylogenesis in trees from locations at different altitudes and latitudes are of great importance as they represent valuable information on the weather-growth relationships required to verify the existence of common climatic factors for xylogenesis (Rossi et al. 2013).

Considering the limitations of this study (i.e., tree selection, sampling method) but also the uniqueness of tracking the timing of the phenological events as they occurred 30 years ago, we defined the aim of this study as: (1) to examine year-to-year variation in the seasonal dynamics of CCP in Norway spruce; and (2) to investigate the relationship between the timing of CCP (onset, duration and end) and local weather conditions during that period.

\section{Materials and methods}

\section{Study site}

The research was conducted in a study site managed by the Institute of Forest Ecology of the Mendel University in Brno (Czech Republic). The plot was located in the monoculture forest area Drahanska vrchovina, $30 \mathrm{~km}$ north of Brno (49 29' 31" $\mathrm{N} ; 16^{\circ} 43^{\prime} 30^{\prime \prime} \mathrm{E}, 600-660 \mathrm{~m}$ a.s.l.). The soil type was modal oligotrophic Cambisol, while the bedrock consisted of intrusive rock acid granodiorite of the Brno Massive (Hruška 1980). It is considered to be a moderate climatic region (Quitt 1971), with average annual air temperature $7.6{ }^{\circ} \mathrm{C}$ and average annual precipitation of $717 \mathrm{~mm}$ (Hadaš 2002).

According to weather data obtained from the Protivanov weather station (Czech Hydrometeorological Institute), which was located approximately $10 \mathrm{~km}$ away from the research site, the coldest temperature in the examined years (1981-1989) was usually reached in the period December-February, with a minimum temperature of -8.6 to $-22.7{ }^{\circ} \mathrm{C}$ (Fig. 1). The warmest period was June-August, with a maximum temperature of 21.9 to $25.6^{\circ} \mathrm{C}$. Annual precipitation ranged from 486 to $793 \mathrm{~mm}$, whereby the wettest months were recorded during the growing season (Tab. 1). In 1983 and 1989 the highest annual mean temperature ( 7.1 and $7.2^{\circ} \mathrm{C}$, respectively) coincided with the lowest annual precipitation amount (486.4 and $499.4 \mathrm{~mm}$, respectively).

Drought indices enable monitoring drought severity, duration and frequency by simplifying complex environmental interactions and quantifying weather extreme values (Tsakiris et al. 2007). The Standardized Precipitation Index (SPI) developed by McKee et al. (1993) was chosen as a well-tested and widely-accepted index of drought severity (Stagge et al. 2015). The SPI is based on the fact that every factor involved in the water resources system (soil moisture content, groundwater, snowpack, river discharges and reservoir storages) eventually depends mostly on the deficit of the precipitation rate over different time scales (McKee et al. 1993, Vicente-Serrano et al. 2010). Many studies have correlated the SPI with other indices, such as the Palmer drought severity index (PDSI - Lloyd-Hughes \& Saunders 2002, Redmond 2002) or the Standardized Precipitation-Evapotranspiration Index (SPEI), derived from SPI by including temperature data for detecting potential evapotranspiration (PET) influence on drought (VicenteSerrano et al. 2010, Gurrapu et al. 2014, Naumann et al. 2014). Vicente-Serrano et al. (2010) reports that the inclusion of PET to calculate the SPEI affects the index only when PET differs from average conditions, for example, under global warming scenarios.

The SPI is based on the long-term precipitation record (for an examined period for any location), which is fitted to a probability distribution transformed into a normal distribution such that the mean SPI for the location and the desired period is zero (McKee et al. 1993, Michaelides \& Pashiardis 2008). The SPI detects drought on multiple time-scales, usually computed over five running time intervals, i.e., 1, 3, 6, 9, and 12 months, but the index is also adjusted to the specific period chosen. Hence, the SPI is particularly suited to compare drought conditions between time periods and regional climatic conditions using only precipitation data. SPI was calculated using the free software package DrinC (Drought Indices Calculator - Tsakiris \& Vangelis 2004). The $\mathrm{SPI}_{\text {annual }}$ was produced based on water years (WY), starting from the previous October up to the current September (each

Tab. 1 - Annual mean air temperature $(\mathrm{T})$ parameters $\left({ }^{\circ} \mathrm{C}\right)$, annual amplitude $(\mathrm{K})$ and annual cumulative precipitation $(\mathrm{P})$ during 1981 1989. The corresponding month is in parenthesis. $\left({ }^{*}\right)$ : Calculation based on monthly maximum and minimum temperature values.

\begin{tabular}{|c|c|c|c|c|c|c|c|c|c|}
\hline Year & $\begin{array}{c}\text { Annual } \\
\text { mean } \mathrm{T}\left({ }^{\circ} \mathrm{C}\right)\end{array}$ & $\begin{array}{c}\text { Annual } \\
\text { maximum } T^{*} \\
\left({ }^{\circ} \mathrm{C}\right)\end{array}$ & $\begin{array}{c}\text { Annual } \\
\text { minimum } T^{*} \\
\left({ }^{\circ} \mathrm{C}\right)\end{array}$ & $\begin{array}{c}\text { Warmest } \\
\text { month T } \\
\left({ }^{\circ} \mathrm{C}\right)\end{array}$ & $\begin{array}{l}\text { Coldest } \\
\text { month T } \\
\left({ }^{\circ} \mathrm{C}\right)\end{array}$ & $\begin{array}{c}\text { Annual } \\
\text { amplitude T } \\
\text { (K) }\end{array}$ & $\begin{array}{c}\text { Annual P } \\
(\mathrm{mm})\end{array}$ & $\begin{array}{l}\text { Highest P } \\
\text { month }(\mathrm{mm})\end{array}$ & $\begin{array}{c}\text { Lowest P } \\
\text { month }(\mathrm{mm})\end{array}$ \\
\hline 1981 & 6.0 & 12.0 & -0.8 & (8) 22.2 & (1) -12.7 & 13.4 & 793.3 & (10) 103.4 & (2) 26.9 \\
\hline 1982 & 6.5 & 12.3 & 0.8 & (6) 21.9 & (1) -13.9 & 11.5 & 525.5 & (8) 113.9 & (2) 0.7 \\
\hline 1983 & 7.1 & 14.3 & 0.0 & (7) 26.6 & (2) -11.2 & 14.3 & 486.4 & (6) 70.9 & (7) 9.2 \\
\hline 1984 & 5.6 & 12.6 & 0.5 & (7) 23.8 & (2) -9.6 & 12.1 & 645.4 & (5) 125.1 & (8) 22.9 \\
\hline 1985 & 5.0 & 12.6 & -2.4 & (8) 22.1 & (2) -19.0 & 15.0 & 849.1 & (9) 190.2 & (11) 16.3 \\
\hline 1986 & 5.8 & 12.4 & -1.4 & (6) 22.0 & (2) -15.9 & 13.7 & 682.0 & (6) 121.1 & (2) 21.4 \\
\hline 1987 & 5.3 & 12.2 & -2.2 & (7) 21.9 & (1) -22.7 & 14.4 & 743.1 & (6) 158.5 & (2) 26.6 \\
\hline 1988 & 6.4 & 12.4 & 0.1 & (7) 25.6 & (12) -11.0 & 12.3 & 613.3 & (8) 119.9 & (4) 10.4 \\
\hline 1989 & 7.2 & 13.6 & 0.9 & (8) 23.6 & (12) -8.6 & 12.7 & 496.4 & (6) 106.9 & (1) 8.6 \\
\hline
\end{tabular}




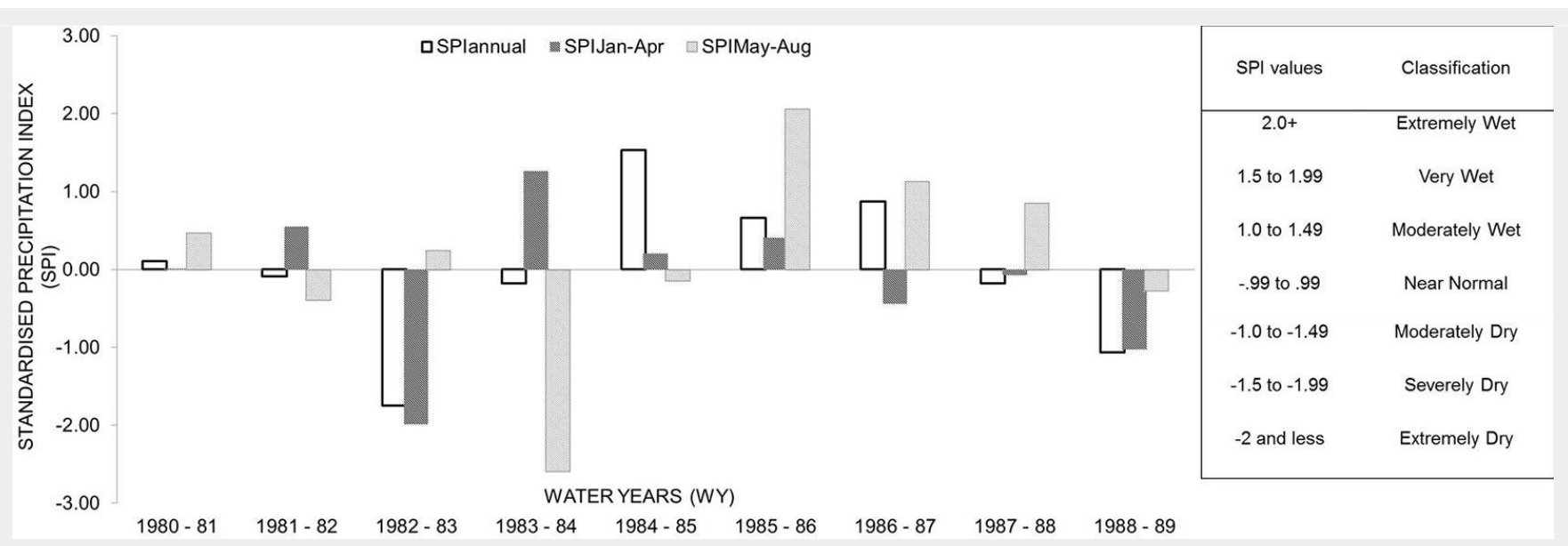

Fig. 2 - Drought events during the examined period according to SPI ${ }_{\text {annual, }}, \mathrm{SPI}_{\text {Jan-Apr }}, \mathrm{SPI}_{\text {May-Aug. Water years }}$ (WY) start from the previous year (October) to the current year (September). The classification of drought conditions according to SPI is reported in the right box.

WY included one growth period). Additionally, both $\mathrm{SPI}_{\text {Jan-Apr }}$ and $\mathrm{SPI}_{\text {May-Aug }}$ were also calculated and adjusted for two 4-month time intervals before and during the growth period (Fig. 2).

The potential relationship between weather conditions and the occurrence of phenological phases was investigated by calculating the Growing Degree Days (GDD), a measure of heat accumulation (McMaster \& Wilhelm 1997). GDD provided an estimation of the cumulative temperature $\left({ }^{\circ} D\right)$ connected with the early phenological phases. Daily $G D D$ was calculated for every tree and year in the examined period (19811989 - Fig. 3) as follows (eqn. 1, eqn. 2):

$$
G D D_{\text {daily }}=\frac{T_{\max }-T_{\min }}{2}-T_{\text {base }}
$$

where $T_{\max }$ and $T_{\min }$ are the maximum and minimum daily air temperatures, respectively, and $T_{\text {base }}$ is the base temperature above which CCP takes place after a certain amount of temperature has been accumulated. A threshold of $5{ }^{\circ} \mathrm{C}$ was chosen for $T_{\text {base }}$ (Schmitt et al. 2004, Gruber et al. 2009). Negative values of $G D D_{\text {daily }}$ were set to zero. $G D D_{\text {daily }}$ values were then summed starting from the $1^{\text {st }}$ day of the year (DOY 1 , $t=1)$ each year until the onset DOY of CCP $(t=n)$ as follows (eqn. 2):

$$
G D D=\sum_{i=1}^{n} G D D_{\text {daily }}
$$

Differences in $G D D$ values among the years were tested using one-way repeatedmeasures ANOVA.

\section{Sample collection and preparation}

Tree selection, sample collection and slide preparation for microscope analysis were performed in 1981. From 1981 to 1989, six dominant and co-dominant Norway spruce trees were selected each year (54 trees in total). Microscopic observations of the intra-annual wood formation were carried out in 2014 on 49 trees (5 trees were excluded due to spoiled slides).

All trees were approximately 75 years old, with diameter at the breast height of about $21 \mathrm{~cm}$ and an average height of $23 \mathrm{~m}$. Sampling was performed at 14-days intervals using a modified hammer-driven cylindrical punch (Doležal's hammer punch - 10 $\mathrm{mm}$ in diameter) around the circumference of the stem, approximately $1.3 \mathrm{~m}$ above the ground. In order to avoid wound effects, sampling points on the stem were separated by at least $10 \mathrm{~cm}$. Microcores of $1 \mathrm{~cm}$ in length were obtained, including the inner phloem, the cambium and at least two most recently formed xylem growth rings. Microcores were immediately immersed in formaldehyde-acetic acid-ethanol solution (FAA) for 24 hours (Wodzicki \& Zajaczkowski 1970), and then rinsed with distilled water, dehydrated in a graded series of ethanol, and finally sectioned using a Jung $\mathrm{K}^{\oplus}$ rotary microtome (Leica, Wetzlar, Germany). Sections $20-40 \mu \mathrm{m}$ in thickness were stained in safranine and light green yellowish SF (triarylmethane dye) and mounted on permanent slides using Canadian Balsam (Horáček et al. 1999). The per-

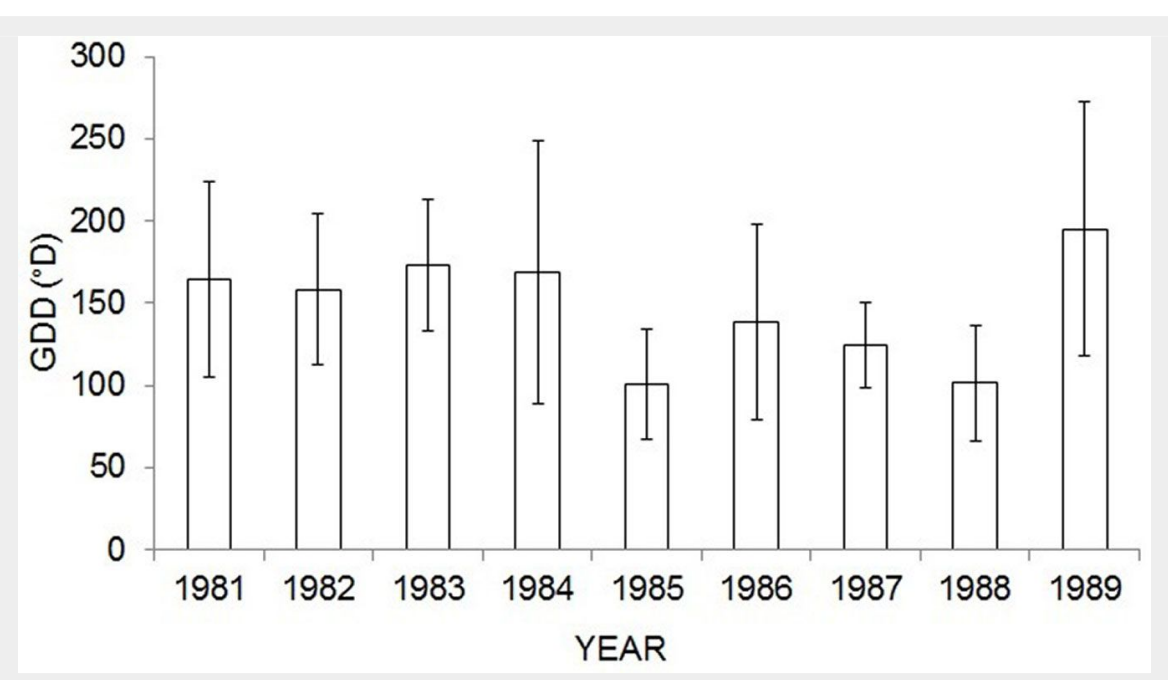

Fig. 3 - Growing degree days (GDD) at the onset of cambial cell production (CCP) in Picea abies by years. $T_{b}=5{ }^{\circ} \mathrm{C}\left(T_{b}=\right.$ base temperature). Columns represent mean values, bars represent standard deviations.

manent slides of cross sections of the sampled tissues were prepared at the end of each growing period and stored.

Observations of cross-sections and histometric analyses were performed in 2014 by a Leica DMLS ${ }^{\oplus}$ microscope (Leica Microsystems, Wetzlar, Germany) connected to a Leica DFC $280^{\oplus}$ digital camera (Leica Microsystems, Wetzlar, Germany). Image processing was carried out using the public-domain software package ImageJ (Abramoff et al. 2004).

\section{Measurements and data processing}

Cambial cells and currently formed xylem cells were counted along three radial files on transverse sections, and then averaged (Deslauriers et al. 2008). For each tree, the following phenological phases of CCP were assessed and the relative DOY computed: (1) the onset of CCP was identified as an increased number of thin-walled cambial derivatives (Rossi et al. 2006b); (2) the cessation of CCP was identified as the time at which no new thin-walled cambial deriva- 


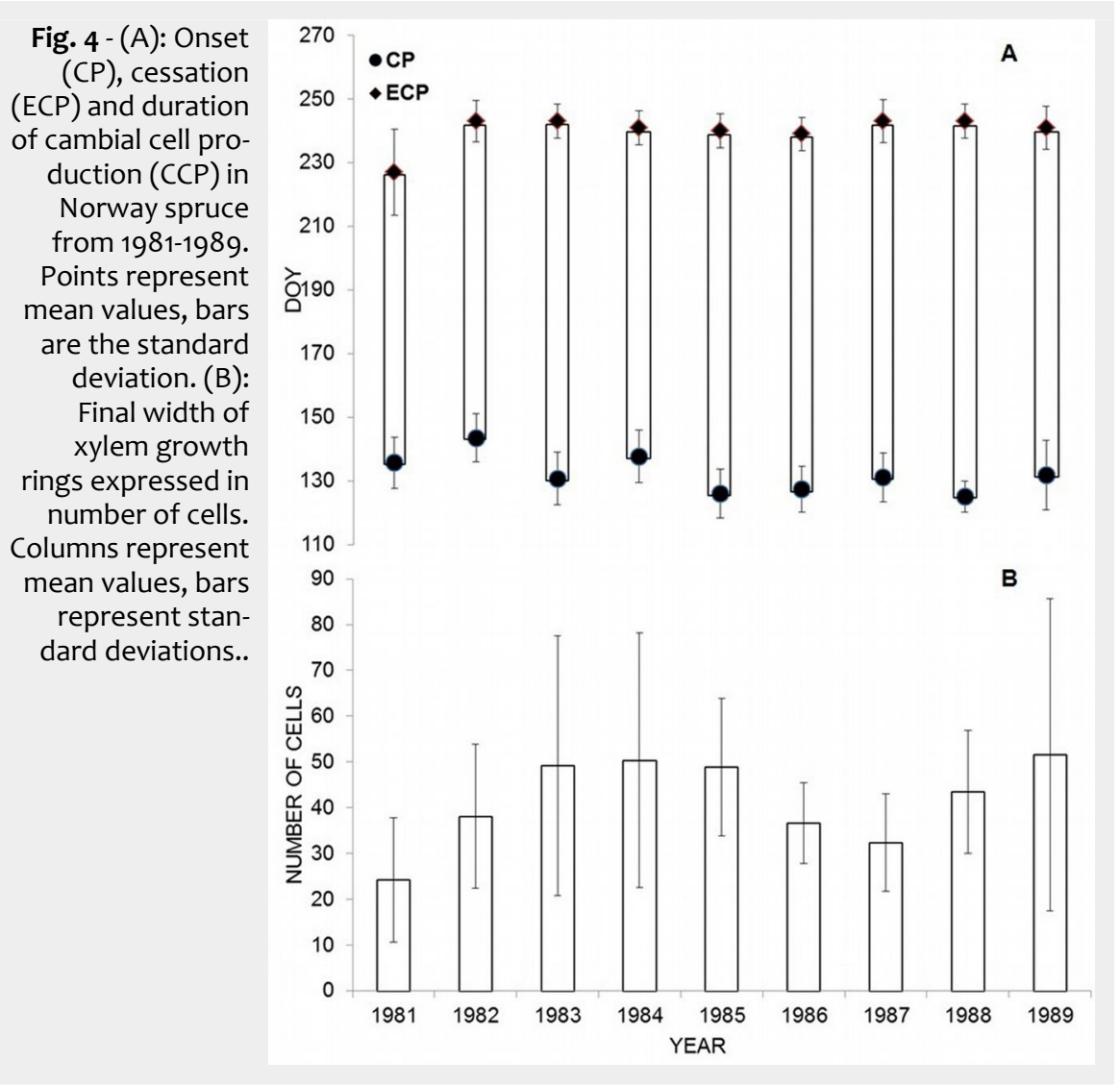

tives were observed adjacent to the cambium and the number of cambial cells was comparable to the number before its reactivation in spring; (3) the duration of the period of CCP was calculated in number of days; (4) the final tree-ring width was expressed as number of cells; (5) the average rate (final number of cell/duration of CCP) of xylem cells produced per day (Gričar et al. 2014); and (6) maximum rate of xylem cells produced per day, which was calculated using a Gompertz function that indicated the maximum growth rate at the inflection point of the curve (Rossi et al. 2003).

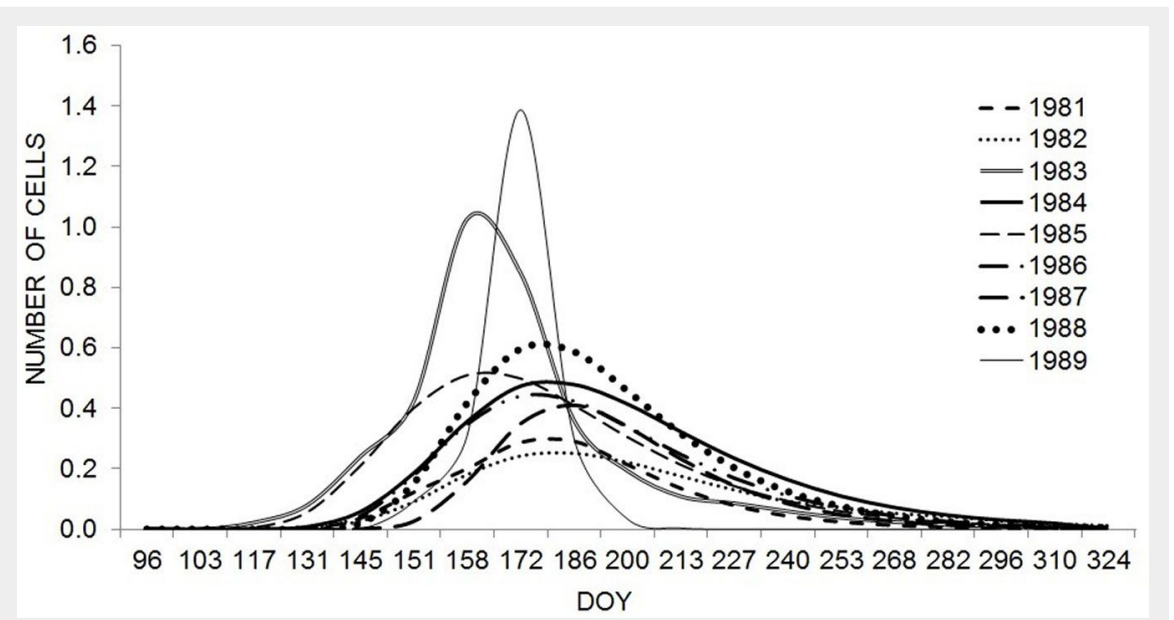

Fig. 5 - First derivatives of Gompertz functions describing xylem growth ring formation in Norway spruce from 1981-1989. The peaks of the function represent the time of maximum rate of cell production (inflection point of the curve). in the rate of production of xylem cells along the growing seasons.

Pearson's correlation coefficients were calculated to measure the strength of association between xylem and tree-ring width, the length of growth season, as well as the rate of cell division. Differences among years in cambial phenology and xylem increments (expressed in number of cells) were tested by individual one-way repeated measures ANOVA.

To analyze the weather-growth relationships, Pearson's correlation coefficients between weather data (precipitation and temperature) and phenological data were calculated. One-way ANOVA was used for analysing cambium phenology and GDD values in comparison with dry/normal/wet conditions. Statistical analysis was carried out using Microsoft Excel $^{\circledR}$ spreadsheets and the IBM SPSS Statistics ${ }^{\circledast}$ software package.

\section{Results}

\section{Weather conditions}

Weather conditions during the growing seasons differed among the nine study years. In general, annual mean temperature was inversely proportional to the annual amount of precipitation, and it was lower in the case of higher rainfall. In addition, the wettest months occurred during the growing season. $\mathrm{SPI}_{\text {annual }}$ values were negative in 1983 and 1989, indicating dry periods, whereas 1985 was the wettest year. The 4-month interval SPI Jan-Apr revealed dry conditions prevailing before the onset of CCP in 1983 and 1989 (WY 19821983 and 1988-1989, respectively) which turned into normal during summer ( $\mathrm{SPI}_{\text {May }}$ Aug). The $\mathrm{SPI}_{\text {May-Aug }}$ depicted the summer drought occurred in 1984. Other study years were considered as normal with regard to water availability.

Comparison of the growing degree days $(G D D)$ showed various amounts of accumulated heat units $\left({ }^{\circ} D\right)$ at the onset of $C C P$ in the nine years $(F=2.66, p<0.0076)$. The highest $G D D$ value was recorded in 1989 $\left(195.10 \pm 80.10^{\circ} \mathrm{D}\right)$ and the lowest in 1985 $\left(100.55 \pm 26.40^{\circ} \mathrm{D}\right)$. The highest variation in $G D D$ among the sampled trees was recorded in 1984 (coefficient of variation: 0.48 ) and the lowest in 1987 (coefficient of variation: 0.21).

\section{Cambium phenology}

The onset of CCP occurred in early May for most of the studied years and ceased by the end of August. CCP lasted longer in 1985 and was shortest in 1989. In the latter year, a delay of almost two weeks was observed compared with the other examined years. The onset, ending and duration of CCP significantly differed among the examined years (onset: $F=2.91, p=0.0012$; ending: $F=2.80, P=0.0015$; duration: $F=$ 2.26, $p=0.04-$ Fig. $4 \mathrm{~A}$ ). Although the widths of annual xylem increments did not differ in the study years $(F=0.841, p=$ 
0.57), the average annual increments were widest in 1989 ( $51.56 \pm 15.94$ cells) and narrowest in 1981 ( $24.22 \pm 7.81$ cells - Fig. 4B).

Similarly, the average rate of cell production also varied between 0.25 and 0.43 among the studied years. The maximum rate of cell production (inflection point of the curve) was reached in the period from 8 June to 6 July and was highest in 1983 and 1989, with 1.02 and 1.4 cells day ${ }^{-1}$, respectively (Fig. 5). However, the peak period of cell production differed, being in 1989 almost three weeks later than in 1983. In other examined years, the maximum production rate ranged from 0.24 (in 1982) to 0.60 cells day ${ }^{-1}$ (in 1988). Despite the summer drought in $1984\left(\mathrm{SPI}_{\text {May-Aug }}=-2.59\right)$, the maximum rate of cell production was 0.47 cells day ${ }^{-1}$.

\section{Weather-growth relationship}

A vast number of possible weathergrowth relationships were examined (Pearsons' correlations) between phenological and weather data (temperature and precipitation of various timings). The strongest weather-growth correlations are reported in the Tab. 2. The onset of CCP strongly correlated with mean temperature in April. The average temperature of the CCP period strongly affected the duration and cessation of CCP. Additionally, the duration of CCP was highly controlled by precipitation during this period. The final number of xylem cells was negatively correlated with mean monthly maximum temperature of June. The maximum rate of produced cells positively correlated with the January-April minimum temperature, as well as with the maximum temperature during CCP. Finally, $G D D$ strongly correlated with the onset and cessation of CCP, the number and the maximum rate of produced cells.

\section{Discussion}

\section{Impact of temperature on CCP onset}

The quantity and quality of the produced wood, as well as the environmental adaptivity of trees are largely determined by the timing of cambial reactivation (Begum et al. 2013). Temperature has been identified as the dominant environmental signal that triggers tree phenology (Körner 2003). Rossi et al. (2008) demonstrated that a threshold temperature plays a decisive role for xylogenesis in conifers growing under cold conditions. A major impact of temperature on the onset of CCP was also clearly demonstrated in experiments of local heating and cooling of spruce stems, causing earlier initiation and higher rates of CCP in the case of heating and a delay in cambial reactivation and lower rates of cell production in the case of cooling (Gričar et al. 2007). In this study, we found that the timing of CCP greatly varied among the studied years. The onset of CCP occurred at the beginning of May and strongly correlated with the mean temperature of April. This is in line with the findings of Gričar et

Tab. 2 - Pearson's correlations for the onset (CP), ending (ECP) and duration of cambial cell production, xylem ring width (expressed in number of cells) and maximum rate of cell production. $(\mathrm{T})$ : temperature $\left({ }^{\circ} \mathrm{C}\right) ;(\mathrm{P})$ : precipitation $(\mathrm{mm}) ;\left({ }^{*}\right): \mathrm{p}<0.05(2-$ tailed).

\begin{tabular}{lllllc}
\hline Weather conditions & CP & ECP & $\begin{array}{c}\text { Duration } \\
\text { of CP }\end{array}$ & $\begin{array}{c}\text { No of } \\
\text { cells }\end{array}$ & $\begin{array}{c}\text { Average } \\
\text { rate } \\
\text { of cells }\end{array}$ \\
\hline$T_{\text {mean }}$ April & $-0.692^{*}$ & - & - & - & - \\
$\mathrm{T}_{\text {mean August }}$ & - & - & - & - & $0.672^{*}$ \\
$\mathrm{~T}_{\text {mean period of duration of CP }}$ & - & - & $-0.671^{*}$ & - & - \\
$\mathrm{T}_{\min }$ Jan - Apr & - & - & - & - & $0.695^{*}$ \\
$\mathrm{~T}_{\min }$ Jan - Aug & - & - & - & - & $0.699^{*}$ \\
$\mathrm{~T}_{\min }$ water years (WY) & - & - & - & $0.694^{*}$ & $0.704^{*}$ \\
$\mathrm{~T}_{\max }$ Jun & - & - & - & $-0.765^{*}$ & $-0.677^{*}$ \\
$\mathrm{~T}_{\max }$ period of duration of CP & - & - & - & - & $0.694^{*}$ \\
$\mathrm{P}_{\text {period of duration of CP }}$ & - & $0.669^{*}$ & $0.735^{*}$ & - & - \\
$\mathrm{P}$ water years (WY) & - & - & - & $-0.709^{*}$ & - \\
$\mathrm{P}$ September-September & - & - & $0.692^{*}$ & - & - \\
GDD & $0.654^{*}$ & $-0.695^{*}$ & - & $0.767^{*}$ & $0.687^{*}$ \\
\hline
\end{tabular}

al. (2014) in Norway spruce. In this study, the annual mean temperature was in general inversely proportional to the annual rainfall; consequently GDD values were highest in 1989 and $1983\left(195.10\right.$ and $172.6^{\circ} \mathrm{D}$, respectively). However, we observed a fairly large variation in the GDD values required for the onset of CCP among the years, indicating that the temperature is not regularly limiting for the growth of spruce at this temperate forest site.

The observation that high winter or early spring temperatures generally promote growth is consistent with the fact that cambial reactivation of evergreen conifers is strictly triggered by a rise of temperature (Gričar et al. 2007, Begum et al. 2013). Since photosynthesis in conifers is possible in winter (Guehl 1985), high temperatures during the winter period could play a positive role in improving carbohydrate storage and growth in the following year. Additionally, warmer winters might decrease embolism (Cochard 1992) and accelerate snowmelt, favoring soil warming and promoting mycorrhizal root growth. Such conditions promote bud formation as well as needle and shoot maturation, thus increasing the growing season of the following year. Finally, these factors, in combination with a suitable water supply, promote early wood formation during spring (Lebourgeois et al. 2010).

\section{Impact of climatic conditions on}

duration and rate of CCP

CCP in the Norway spruce ceased by the end of August, which is in accordance with observations by other studies on this species (Horáček et al. 1999, Gričar et al. 2014). The amount of precipitation proved to be the main factor that positively influenced the duration of CCP, whereas the average rate of cell production positively correlated with the monthly minimum temperature in January-April, as well as with the monthly maximum temperature during the growing period. The timing of the cessation of CCP was more variable among trees and years as compared with its onset. The tempera- ture at the end of cell production was still high and favorable for radial growth. In previous studies, this has been explained by the need to ensure enough time for the development of the latest formed tracheids before winter, which in wide xylem rings can last up to two months after the cessation of cell production (Gričar et al. 2005, Rossi et al. 2008).

The minimum temperature during $W Y$ strongly correlated with the production of cells and daily tree growth. The years 1983 and 1989 were found to be dry according

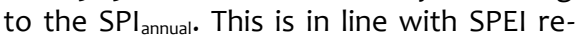
sults from a recent study conducted in the Czech Republic (Potop et al. 2014). Although the years 1983 and 1989 were identified as dry years according to the $\mathrm{SPI}_{\text {annual, }}$, they were characterized by the fastest production of cells. However, it has to be stressed again that drought occurred before the growing season $\left(\mathrm{SPI}_{\text {Jan-Apr }}\right)$, while conditions changed to normal during the growing season (SPI $\mathrm{May}_{\text {-Aug }}$ ). In the case of 1983 , CCP started earlier, reaching the maximum rate of cell production ( 1.02 cells day $^{-1}$ ) also earlier. In 1989, an even higher maximum rate of cell production ( 1.4 cells day ${ }^{-1}$ ) was reached in a short period of almost 20 days. Recent study on spruce growing in temperate forests resulted in $0.44 \pm 0.03$ cells day ${ }^{-1}$ (Cuny et al. 2012). The maximum rate of cell produced during the summer drought in 1984 was in line with Cuny et al. (2012), presumably due to moderately wet conditions prevailing before the growing season. Nevertheless, we did not find any strong correlation between the duration of cell production and the timing of maximum cell production or the rate of cell production.

\section{Impact of temperature and}

\section{precipitation on xylem increments}

In numerous studies on radial growth of tree-rings conducted in central and northern Europe, temperature was identified as the primary growth factor at higher altitudes (Waldner \& Schweingruber 1996, Mäkinen et al. 2000, Miina 2000, Rossi et al. 
2008), though precipitation also controls radial growth especially at low altitudes (Lebourgeois et al. 2010, Bošela et al. 2014). We found a positive relationship between the final width of the annual xylem increments and $G D D$ values, but negative with maximum temperature in June. In northern Europe, June temperature is usually the most important factor (Mäkinen et al. 2003, Andreassen et al. 2006). At high elevation sites, the response of Norway spruce to the mean temperature in summer months is positive, while it is negative at lower elevation sites (Levanič et al. 2009). An increase in mean summer temperature is usually associated with a decrease in precipitation and represents the limiting factor for spruce at lower altitudes (Bošela et al. 2014). In our case, precipitation did not appear to play an important role on ring width, as had been found for temperature.

In general, ring widths depend on the duration and rate of CCP (Skene 1972). In this study, xylem widths were predominantly related to the rate of cell production. The maximum rate of cell production was reached in the period from 8 June until 6 July, which is in line with the observation of Rossi et al. (2006a). These authors reported that maximum daily growth rates in conifers at colder sites in the northern hemisphere occur approximately at the summer solstice. This photoperiodic growth constraint is thus an adaptation of trees to native climatic conditions, allowing them to complete differentiation of terminal latewood cells before winter (Rossi et al. 2006a). Unlike temperature, the photoperiod is the same at a given date and locality each year. The cessation of growth in response to declining photoperiods is thus an indirect adaptation to the temperature regime (Ekberg et al. 1979).

\section{Conclusions}

Xylem formation studies are usually conducted on trees growing near either timberline or xeric habitats, where primarily temperature or water availability are expected to play a key role on growth (Eilmann et al. 2011, Oberhuber et al. 2014, Treml et al. 2015). Similar studies in temperate regions are more complicated, since the growth may be also driven by many biotic and abiotic factors (Carrer et al. 2012, Fisher \& Neuwirth 2013). Local site conditions, tree age, tree competition, tree vitality, as well as different forest management practices, can be more important drivers of local-scale growth trends than the regional climate signal (Levanič et al. 2009, Mamet \& Kershaw 2013). Our results showed that the timing of CCP and the widths of xylem cells were influenced by temperature and precipitation. However, the weather-xylem growth relations of Norway spruce growing under average climatic conditions in temperate forests are not explicit. Since trees respond less drastically to normal conditions (Mäkinen et al. 2003), further investigations are needed to elucidate the relationship between weather conditions and tree growth.

\section{Acknowledgements}

KG together with JG developed the concept of the paper, wrote the paper, prepared the figures and tables and performed the wood-anatomical analysis; VG provided the cross-sections and performed the wood-anatomical measurements and helped to develop the concept of the paper; $\mathrm{HV}$ helped to prepare the figures and measurements, wrote some parts of the results and discussion.

The authors gratefully acknowledge the help of the xylogenesis research team from the 1980s: A. Matovič, J. Šlezingerová, L. Gandelová, V. Štepánek and Z. Fouskova for their work in the field and in the laboratory. The work was supported by the Postdoc Project CZ.1.07/2.3.00/30.0031 at MENDELU and the state budget of the Czech Republic, Project Indicators of Trees Vitality Reg. No. CZ.1.07/2.3.00/20.0265. The cooperation among the international partners was supported by COST Action FP1106 "STReESS". We thank Martin Cregeen for language editing. Our special thanks to the Czech Hydrometeorological Institute for providing us with the long-term weather data.

\section{References}

Abramoff MD, Magalhaes PJ, Ram SJ (2004). Image processing with ImageJ. Biophotonics International 11: 36-42.

Andreassen K, Solberg S, Tveito OE, Lystad SL (2006). Regional differences in climatic responses of Norway spruce (Picea abies (L.) Karst) growth in Norway. Forest Ecology and Management 222: 211-221. - doi: 10.1016/j.foreco.2005.10. 029

Battipaglia G, Saurer M, Cherubini P, Siegwolf RTW, Cotrufo MF (2009). Tree rings indicate different drought resistance of a native (Abies alba Mill.) and a nonnative (Picea abies Karst.) species co-occurring at a dry site in Southern Italy. Forest Ecology and Management 257: 820-828. - doi: 10.1016/j.foreco.2008.10.015

Begum S, Nakaba S, Yamagishi Y, Oribe Y, Funada $R$ (2013). Regulation of cambial activity in relation to environmental conditions: understanding the role of temperature in wood formation of trees. Physiologia Plantarum 147: 4654. - doi: 10.1111/j.1399-3054.2012.01663

Boden S, Kahle HP, Von Wilpert K, Spiecker H (2014). Resilience of Norway spruce (Picea abies (L.) Karst) growth to changing climatic conditions in Southern Germany. Forest Ecology and Management 315: 12-21. - doi: 10.1016/j.for eco.2013.12.015

Bošela $M$, Sedmák R, Sedmákova $D$, Marušák $R$, Kulla L (2014). Temporal shifts of climategrowth relationships of Norway spruce as an indicator of health decline in the Beskids, Slovakia. Forest Ecology and Management 325: 108-117. - doi: 10.1016/j.foreco.2014.03.055 Carrer M, Motta R, Nola P (2012). Significant mean and extreme climate sensitivity of Norway spruce and silver fir at mid-elevation mesic sites in the Alps. PLoS ONE 7 (11): e50755. - doi: 10.1371/journal.pone.0050755

Cochard H (1992). Vulnerability of several conifers to air embolism. Tree Physiology 11: 73-83. doi: 10.1093/treephys/11.1.73

Cuny HE, Rathgeber CBK, Lebourgeois F, Fortin $M$, Fournier $M$ (2012). Life strategies in intraannual dynamics of wood formation: example of three species in a temperate forest in northeast France. Tree Physiology 32: 612-625. - doi: 10.1093/treephys/tps039

Desplanque C, Rolland C, Michalet R (1998). Dendroécologie comparée du sapin blanc (Abies alba) et de l'épicéa commun (Picea abies) dans une vallée alpine de France [Comparative dendroecology of white fir (Abies alba) and Norway spruce (Picea abies) in an alpine valley of France]. Canadian Journal of Forest Research 28: 737-748. [in French] - doi: 10.1139/x98-025 Deslauriers A, Morin H (2005). Intra-annual tracheid production in balsam fir stems and the effect of meteorological variables. Trees 19: 402408. - doi: 10.1007/s00468-004-0398-8

Deslauriers A, Rossi S, Anfodillo T, Saracino A (2008). Cambial phenology, wood formation and temperature thresholds in two contrasting years at high altitude in southern Italy. Tree Physiology 28: 863-871. - doi: 10.1093/treephys/ 28.6.863

Eilmann B, Zweifel R, Buchmann N, Graf Pannatier E, Rigling A (2011). Drought alters timing, quantity, and quality of wood formation in Scots pine. Journal of Experimental Botany 62: 2763-2771. - doi: 10.1093/jxb/erq443

Ekberg I, Eriksson G, Dormling I (1979). Photoperiodic reactions in conifer species. Ecography 2 (4): 255-263. - doi: 10.1111/j.1600-0587.1979.tbo12 97.x

Fisher S, Neuwirth B (2013). Vulnerability of trees to climate events in temperate forests of West Germany. ISRN Forestry 2013: 1-15. - doi: 10.1155/ 2013/201360

Guehl JM (1985). Comparative study of the winter photosynthetic potential of three evergreen conifers of the temperate zone (Pseudotsuga menziesii Mirb., Abies alba Mill. and Picea excelsa Link.). Annales des Sciences Forestières 42: 23-38. - doi: 10.1051/forest:19850102 Gurrapu S, Chipanshi A, Sauchyn D, Howard A (2014). Comparison of the SPI and SPEI on predicting drought conditions and streamflow in the Canadian prairies. In: Proceedings of the " $28^{\text {th }}$ Conference of Hydrology $-94^{\text {th }}$ American Meteorological Society Annual Meeting". Atlanta (GA, USA) 2-6 Feb 2014. American Meteorological Society, Boston, MA, USA, pp. 7. [online] URL: http://ams.confex.com/ams/94An nual/webprogram/Paper241519.html

Gričar J, Cufar K, Oven P, Schmitt U (2005). Differentiation of terminal latewood tracheids in silver fir trees during autumn. Annals of Botany 95: 959-965. - doi: 10.1093/aob/mci112

Gričar J, Zupančič M, Cufar K, Oven P (2007). Regular cambial activity and xylem and phloem formation in locally heated and cooled stem portions of Norway spruce. Wood Science and Technology 41: 463-475. - doi: 10.1007/s00226006-0109-2

Gričar J, Prislan P, Gryc V, Vavrčík H, De Luis M, Cufar K (2014). Plastic and locally adapted phenology in cambial seasonality and production 
of xylem and phloem cells in Picea abies from temperate environments. Tree Physiology 34: 869-881. - doi: 10.1093/treephys/tpu026

Gruber A, Zimmermann J, Wieser G, Oberhuber $W$ (2009). Effects of climate variables on intraannual stem radial increment in Pinus cembra (L.) along the alpine treeline ecotone. Annals of Forest Science 66: 503. - doi: 10.1051/forest/20 09038

Hadaš P (2002). Temperature and precipitation condition in the high elevation spruce stands of Drahanska vrchovina upland. Ekologia 21: 6987.

Horáček P, Šlezingerová J, Gandelová L (1999). Effects of environment on the xylogenesis of Norway Spruce (Picea abies L. Karst.). In: "Tree ring analysis: biological, methodological, and environmental aspects" (Wimmer R, Vetter RE eds). CABI International, University Press, Cambridge, UK, pp. 33-53. [online] URL: http:// www.cabdirect.org/abstracts/19990609826.ht $\mathrm{ml}$

Hruška B (1980). Geological petrographic ratios, physical weathering processes, nutrient releasing and classification of physical weathering processes in spruce forest ecosystem. Final report VI-2-2-20, VŠZ Brno, Czech Republic, pp. 51. [in Czech]

IPCC (2013). Climate change 2007: the physical science basis. Contribution of Working Group I to the Fourth Assessment Report of the Intergovernmental Panel on Climate Change. Technical report (Solomon S, Qin D, Manning $M$, Chen Z, Marquis M, Averyt KB, Tignor M, Mille $\mathrm{HL}$ eds). Ambridge University Press, Cambridge, UK and New York, USA, pp. 996.

Jyske T, Hölttä T, Mäkinen H, Nöjd P, Lumme I, Spiecker $H$ (2010). The effect of artificially induced drought on radial increment and wood properties of Norway spruce. Tree Physiology 30: 103-115. - doi: 10.1093/treephys/tppog9

Körner C (2003). Carbon limitation in trees. Journal of Ecology 91: 4-17. - doi: 10.1046/j.1365-27 45.2003.00742.x

Lebourgeois F, Rathgeber CBK, Ulrich E (2010). Sensitivity of French temperate coniferous forests to climate variability and extreme events (Abies alba, Picea abies and Pinus sylvestris). Journal of Vegetation Science 21: 364-376. - doi: 10.1111/j.1654-1103.2009.01148.x

Levanič T, Gričar J, Gagen M, Jalkanen R, Loader NJ, McCarroll D, Oven P, Robertson I (2009). The climate sensitivity of Norway spruce [Picea abies (L.) Karst.] in the southeastern European Alps. Trees 23: 169-180. - doi: 10.1007/s00468008-0265-0

Li X, Liang E, Gričar J, Prislan P, Rossi S, Cufar K (2012). Age dependence of xylogenesis and its climatic sensitivity in Smith fir on the southeastern Tibetan Plateau. Tree Physiology 33: 48-56. - doi: 10.1093/treephys/tps113

Lloyd-Hughes B, Saunders MA (2002). A drought climatology for Europe. International Journal of Climatology 22: 1571-1592. - doi: 10.1002/joc. 846

Lupi C, Morin H, Deslauriers A, Rossi S (2010). Xylem phenology and wood production: resolving the chicken-or-egg dilemma. Plant Cell and Environment 33: 1721-1730. - doi: 10.1111/j.13653040.2010.02176.x

Mäkinen H, Nöjd P, Mielikainen K (2000). Clima- tic signal in annual growth variation of Norway spruce (Picea abies) along a transect from central Finland to the Arctic timberline. Canadian Journal of Forest Research 30: 769-777. - doi: 10.1139/x00-005

Mäkinen H, Nöjd P, Saranpaa P (2003). Seasonal changes in stem radius and production of new tracheids in Norway spruce. Tree Physiology 23: 959-968. - doi: 10.1093/treephys/23.14.959

Mamet SD, Kershaw GP (2013). Age-dependency, climate, and environmental controls of recent tree growth trends at subarctic and alpine treelines. Dendrochronologia 31: 75-87. - doi: 10.101 6/j.dendro.2012.08.002

McKee TB, Doesken NJ, Kleist J (1993). The relationship of drought frequency and duration to time scale. In: Proceedings of the " 8 th Conference on Applied Climatology". Anaheim (CA, USA), 17-22 Jan 1993. American Meteorological Society, Boston, MA, USA, pp. 179-184. [online] URL: http://ccc.atmos.colostate.edu/relationsh ipofdroughtfrequency.pdf

McMaster G, Wilhelm WW (1997). Growing degree-days: one equation, two interpretations. Agricultural and Forest Meteorology 87: 291300. - doi: 10.1016/S0168-1923(97)00027-0

Michaelides S, Pashiardis S (2008). Monitoring drought in Cyprus during the 2007-2008 hydrometeorological year by using the Standardized Precipitation Index (SPI). European Water 23/ 24: 123-131. [online] URL: http://www.research gate.net/publication/268343168

Miina J (2000). Dependence of tree-ring, earlywood and latewood indices of Scots pine and Norway spruce on climatic factors in eastern Finland. Ecological Modelling 132: 259-273. - doi: 10.1016/S0304-3800(00)00296-9

Ministry Report (2014). Report on forest and forestry in the Czech Republic by 2013. Ministry of Agriculture of the Czech Republic, Prague, Czech Republic, pp. 30. [online] URL: http:// eagri.cz/public/web/file/353116/Zprava_o_stavu _lesa_2013_ENG.pdf

Naumann G, Dutra E, Barbosa P, Pappenberger F, Wetterhall F, Vogt JV (2014). Comparison of drought indicators derived from multiple data sets over Africa. Hydrology and Earth System Sciences 18: 1625-1640. - doi: 10.5194/hess-18-16 25-2014

Oberhuber W, Gruber A, Kofler W, Swidrak I (2014). Radial stem growth in response to microclimate and soil moisture in a droughtprone mixed coniferous forest at an inner Alpine site. European Journal of Forest Research 133: 467-479. - doi: 10.1007/s10342-013-0777-z

Potop V, Boroneant C, Možný M, Štepánek P, Skalák P (2014). Observed spatiotemporal characteristics of drought on various time scales over the Czech Republic. Theoretical and Applied Climatology 115: 563-581. - doi: 10.1007/so 0704-013-0908-y

Quitt E (1971). Climatic areas of Czechoslovakia. Geograficky ustav CSAV, Brno, Czech Republic, pp. 80. [in Czech]

Redmond KT (2002). The depiction of drought. Bulletin of the American Meteorological Society 83: 1143-1147. - doi: 10.1175/1520-0477(2002) 083<1143:TDODAC>2.3.CO;2

Richardson SD, Dinwoodie JM (1960). Studies on the physiology of xylem development. Journal of the Institute of Wood Science 6: 3-13. [online] URL: http://www.cabdirect.org/abstra cts/19600605596.html

Rossi S, Deslauriers A, Morin H (2003). Application of the Gompertz equation for the study of xylem cell development. Dendrochronologia 21: 33-39. - doi: 10.1078/1125-7865-00034

Rossi S, Deslauriers A, Anfodillo T, Morin H, Saracino A, Motta R, Borghetti M (2006a). Conifers in cold environments synchronize maximum growth rate of tree-ring formation with day length. New Phytologist 170: 301-310. - doi: 10.1111/j.1469-8137.2006.01660.x

Rossi S, Deslauriers A, Anfodillo T (2006b). Assessment of cambial activity and xylogenesis by microsampling tree species: an example at the Alpine timberline. IAWA Journal 27: 383-394. doi: 10.1163/22941932-90000161

Rossi S, Deslauriers A, Gričar J, Seo JW, Rathgeber CBK, Anfodillo T, Morin H, Levanič T, Oven $P$, Jalkanen R (2008). Critical temperatures for xylogenesis in conifers of cold climates. Global Ecology and Biogeography 17: 696-707. - doi: 10.1111/j.1466-8238.2008.00417.x

Rossi S, Anfodillo T, Cufar K, Cuny HE, Deslauriers A, Fonti P, Frank D, Gričar J, Gruber A, King $\mathrm{GM}$, Krause C, Morin H, Oberhuber W, Prislan P, Rathgeber CBK (2013). A meta-analysis of cambium phenology and growth: linear and non-linear patterns in conifers of the northern hemisphere. Annals of Botany 112: 1911-1920. - doi: 10.1093/aob/mct243

Schmitt U, Jalkanen R, Eckstein D (2004). Cambium dynamics of Pinus sylvestris and Betula spp. in the northern boreal forest in Finland. Silva Fennica 38: 167-178. - doi: 10.14214/sf.426 Schuster R, Oberhuber W (2013). Age-dependent climate-growth relationships and regeneration of Picea abies in a drought-prone mixed-coniferous forest in the Alps. Canadian Journal of Forest Research 43: 609-618. - doi: 10.1139/cjfr-20120426

Skene DS (1972). The kinetics of tracheid development in Tsuga canadensis Carr. and its relation to tree vigour. Annals of Botany 36: 179187. [online] URL: http://aob.oxfordjournals.org /content/36/1/179.short

Skrøppa T (2003). EUFORGEN - Technical guidelines for genetic conservation and use for Norway spruce (Picea abies). International Plant Genetic Resources Institute, Rome, Italy, pp. 6. [online] URL: http://www.euforgen.org/fileadm in/bioversity/publications/pdfs/EUFORGEN/856 Stagge JH, Tallaksen LM, Gudmundsson L, Van Loon AF, Stahl K (2015). Candidate distributions for climatological drought indices (SPI and SPEI). International Journal of Climatology 2015: 1-14. - doi: 10.1002/joc.4267

Tsakiris G, Vangelis H (2004). Towards a drought watch system based on spatial SPI. Water Resources Management 18: 1-12. - doi: 10.1023/B: WARM.0000015410.47014.a4

Tsakiris G, Pangalou D, Vangelis H (2007). Regional drought assessment based on the Reconnaissance Drought Index (RDI). Water Resources Management 21: 821-833. - doi: $10.1007 /$ s11269-0o6-9105-4

Treml V, Kašpar J, Kuelavá H, Gryc V (2015). Differences in intra-annual wood formation in Picea abies across the treeline ecotone, Giant Mountains, Czech Republic. Trees 29: 515-526. doi: 10.1007/s00468-014-1129-4 
Vicente-Serrano SM, Beguería S, López-Moreno JI (2010). A multi-scalar drought index sensitive to global warming: the Standardized Precipitation Evapotranspiration Index - SPEl. Journal of Climate 23: 1696-1718. - doi: 10.1175/2009JCLI29 09.1
Waldner PO, Schweingruber FH (1996). Temperature influence on decennial tree-ring width and density fluctuations of subalpine and boreal conifers in Western Europe since 1850 A.D. Dendrochronologia 14: 127-151.

Wodzicki TJ, Zajaczkowski S (1970). Methodical problems in studies on seasonal production of cambial xylem derivatives. Acta Societatis Botanicorum Poloniae 39: 509-520. - doi: 10.5586/as bp.1970.040 